\title{
Learning in an agile setting: A multilevel research study on the evolution of organizational routines
}

\author{
Maria Carmela Annosi ${ }^{\mathrm{a}}$, Antonella Martini ${ }^{\mathrm{b}}$, Federica Brunetta ${ }^{\mathrm{c}}$, Lucia Marchegiani ${ }^{\mathrm{d}, *}$

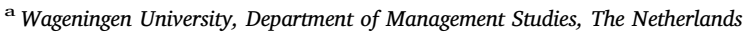 \\ b University of Pisa, School of Engineering, Italy \\ ${ }^{\mathrm{c}}$ LUISS Guido Carli University, Department of Business and Management, Italy \\ ${ }^{\mathrm{d}}$ Roma Tre University, Department of Business Studies, Italy
}

\section{A R T I C L E I N F O}

\section{Keywords:}

Agile

Organizational learning

Knowledge

Self-managing team

Routine evolution

Multiple case studies

\begin{abstract}
A B S T R A C T
Recognizing a serious lack of research on routinized individual actions and organizational adaptation in the stability-change paradox, we intend to provide an in-depth explanation of the way in which agile methods affect organizational learning in self-managed, team-based organizations, taking a multi-level evolutionary approach. We explore learning in agile organizations by breaking the analysis of organizational routines down into different levels - individual, team and organization - and describing the process of variation, selection and retention of routines at each level. Leveraging on multiple case studies, we discuss how team members learn and gain knowledge, from both direct and indirect experience, and analyze how teams develop conceptual frameworks and interpret those experiences. Finally, we discuss how organizational memory develops and how teams in agile organizations adapt simultaneously within an ecological structure that also comprises the changing environment. Our findings reveal substantial flaws in the capacity of agile methods to foster organizational learning.
\end{abstract}

\section{Introduction}

Previous research indicates that organizations learn through routines that enable them to apply, store and develop new knowledge systematically (Levitt \& March, 1988; Nelson \& Winter, 1982). Specifically, routines are the core of the firm, and organizational learning takes place when an organization develops "adaptation routines" that permit change in existing routines, on the basis of new knowledge (Nelson \& Winter, 1982). These adaptation routines consist of interacting parts; the interaction "creates an on-going opportunity for variation, selection, and retention of new practices and patterns of action within routines and allows routines to generate a wide range of outcomes, from apparent stability to considerable change" (Feldman \& Pentland, 2003, p. 94). However, the way in which the stability of these adaptation routines facilitates organizational adaptation - through flexible recombination of stable routines, stable (systematic) approaches to exploration, or stable (repeated) allocation of resources to change tasks - has yet to be systematically analyzed (Yi, Knudsen, \& Becker, 2016). The stability-change paradox reflects a significant shortcoming in current research on routines and organizational adaptation (Yi et al., 2016) and also underlines the need to discover how the micro-processes of routinized individual actions influence organizational phenomena. Little attention has been paid to disclosing the micro-processes related to individual "decision-routines" (Betsch, Haberstroh, \& Hohle, 2002, p. 456) involved in the link between organizational routine-level inertia and organizational inertia/adaptation (Abell, Felin, \& Foss, 2008; Salvato \& Rerup, 2011).

This article discusses the micro-processes through which self-managed, team-based organizations that apply agile scrum practices to develop their software (Schwaber \& Beedle, 2002) improve routinized activities aimed at the development and adaptation of organizational routines. Our research focuses specifically on agile software development. Departing from the paradigm that organizations must seek mass production efficiencies through bureaucratic structures, hierarchical organization, and centralized control over production, agile scrum software practices present, at their core, the need for flexible, learning organizations that constantly adapt and resolve emerging problems thanks to the coordinated work of self-managed teams. Scrum practices, in fact, include feedback loops as a mechanism to trigger a cyclical process in which team members check the effectiveness of their own solutions and respond to the specific feedback in a variety of ways, ranging from changes in their behavior to revision of their strategies

\footnotetext{
* Corresponding author.

E-mail addresses: maria.annosi@wur.nl (M.C. Annosi), a.martini@ing.unipi.it (A. Martini), fbrunetta@luiss.it (F. Brunetta), lucia.marchegiani@uniroma3.it (L. Marchegiani).
} 
(Schwaber, 1997; Moe, 2013).

In scrum, problems are detected and managed at the level of teams through new practices of delegation designed to heighten the emotional and cognitive involvement of team members. A significant example of agile scrum routines is retrospective, which allows team members to reflect on ways to improve the organizational routines they are involved in by collectively identifying solutions to the problems found in the latest work iterations. The concept of organizational leadership without control is thus implemented in agile scrum, using as source of influence qualities of culture, shared values among team members to set directions, and routines to coordinate the activities and the information that team members manipulate within an organization (Annosi \& Brunetta, 2017, 2018; Annosi, Foss, Brunetta, \& Magnusson, 2017). But how can organizational routines match with the changing environment in the agile scrum context and continuously adapt through agile flow processes? Positing that knowledge is embodied in the organizational routines and any change in them is a sign of change in knowledge (Argote \& Miron-Spektor, 2011; Levitt \& March, 1988), our discussion relies on the description of multi-level learning processes, including the experiential processes of learning-by-doing, and of vicarious learning by team members, as well as the processes that underlie the interpretation of experience with teams, the organizational memory, and ecologies of learning (Levitt \& March, 1988), through which collective knowledge is articulated and codified in the entire organization.

All these learning processes, which take place at individual, team and organizational level, are responsible for the variation, selection and retention of routines (Crossan, Maurer, \& White, 2013). We assume that at each level the processes of variation, selection, and retention occur over time (Aldrich, 1999). However, the levels of analysis - individual, team, organization - are linked and intertwined, not standalone (Campbell, 1990). Accordingly, this study embraces a multi-level perspective of organizational learning, linking the three levels of analysis while describing the variation, selection and retention routine processes at each level.

By examining the relationships among entities at the distinct levels of analysis, we reconstruct the evolutionary pattern that each routine may have, following bottom-up and top-down processes, and derive better insights into organizational adaptability when agile scrum practices are adopted (Schwaber \& Beedle, 2002).

The paper is structured as follows. First (Section 2) we set out the theoretical background in order to provide a clear account of the theoretical basis of our analysis in terms of organizational learning and agile development as well as our own contributions to overcome research gaps in these fields; next (Section 3), we describe the methodological approach we pursued. The results are then presented (Section 4) and extensively discussed (Section 5), developing the multi-level framework. Section 6 sets out concluding remarks, managerial contributions and possible areas for future research.

\section{Theoretical background}

Agile organizational forms have emerged as a response to the increasing complexity. The volatility of markets, the hyper-competitive economic environment, the new threats of globalization, and the knowledge-based competition induced by accelerating technological change explain the current managerial practice of engaging in organizational experiments without the support of validated theories (Daft \& Lewin, 1993). Examples of experiments carried out by managers (Daft \& Lewin, 1993) consist in agile, modular, cluster, learning, or network organizations, in virtual or spinout corporations, and even in perpetual matrix (Bartlett \& Ghoshal, 1989; Miles \& Snow, 1986; Morris \& McManus, 2006). These new organizational forms share a number of elements, such as decentralized decision-making processes, self-organizing units, flatter hierarchies, permeable boundaries (both external and internal), employee empowerment, renewal capacity, and coordination mechanisms characterized by self-integration (Daft \& Lewin,
1993). In these new organizations, leadership is distributed among agents who interact in "complex feedback networks" (Avolio, Walumbwa, \& Weber, 2009: 430), thus allowing for adaptive outcomes such as learning, innovation, and adaptive capacity in the context of organizational activities (Uhl-Bien, Marion, \& McKelvey, 2007). Leadership is shifted from one or several individuals to the social and relational interactions of autonomous agents (Avolio et al., 2009; Hazy \& Uhl-Bien, 2013), shaped by agile scrum routines. Analyzing the learning processes responsible for the variation, selection and retention of routines, we examine how agile scrum practices influence the capacity of organizations both to react defensively and to use the knowledge so acquired offensively, improving the fit between the organization and the environment.

Organizational learning is defined as "a change in the organization that occurs as the organization acquires experience" (Argote \& MironSpektor, 2011, p. 1124). Specifically, the change may take place in the organization's knowledge following the accumulation of experience (Fiol \& Lyles, 1985; Peruffo, Marchegiani, \& Vicentini, 2018). Human interactions, in the form of routines, are seen as the main source of knowledge and knowledge transfer (Argote \& Ingram, 2000). Organizational routines are "the organizational analogue of individual skill" (Nelson \& Winter, 2002, p. 30). However, given that routines arise at function or group level, whereas skills are individual attributes (Cohen et al., 1996), routines do not refer to skills that are owned and in common to many individuals in an organization or a team. Routines are, in fact, "organizational meta-habits, existing on a substrate of habituated individuals in a social structure. Routines are one ontological layer above habits themselves" (Hodgson, 2008, p. 18). The relationship between organizational routines and individual skills has been relatively little scrutinized and is viewed primarily through the consideration that routines are "skill-like" (Feldman \& Pentland, 2003).

Thus there arose a major "challenge for micro-research" (Greve, 2008, p. 199). This challenge is particularly relevant within the current agile literature, as previous studies have mostly focused on the knowledge, skills and learning of individual employees (Nagel \& Dove, 1991; Plonka, 1997), paying only limited attention to organizational and team-level learning (Dyer \& Shafer, 2003) after the adoption of agile scrum routines.

Notwithstanding the diffusion and specificity of the agile scrum routines, rigorous empirical research on the evaluation of learning following their adoption is still limited (Abrahamsson, Conboy, \& Wang, 2009). The literature has generally neglected the effectiveness of agile routines for the organization, especially the analysis of their impact on specific long-term outcomes that require organizational adaptation, such as innovation and learning (Senapathi \& Srinivasan, 2012).

The foregoing considerations suggest some particular research questions: How do individual-level competences acquired through agile routines relate to organizational-level routines? How do organizational routines change and adapt in agile team based organizations?

Competences, defined as individuals' knowledge and skills in performing a particular task (Shippmann et al., 2000), constitute a good basis for the bridge between the individual and the organizational level of analysis (Salvato \& Rerup, 2011). Therefore, investigating how agile teams and organizations learn, starting from the accumulation of individual competence, requires analyzing how the emerging routines of teams and organizations evolve once individual learning results are achieved. This allows us to examine how individual-level "decisionroutines" (Betsch et al., 2002, p. 456) are linked to group and organizational routines and how the latter adapt over time. Given this need, we embrace an ecology of learning that, through a multi-level perspective, observes the evolutionary dynamics of learning routines, following the thesis that learning within the organization follows a cyclical pattern involving the individual, the team and the organizational levels (Zollo \& Winter, 2002). 


\subsection{Routine-based learning}

Routines, understood as forms, rules, procedures, and strategies, can be regarded as consolidated courses of action that allow organizations to attain their objectives by the involvement of individuals, and through their interdependent actions (Feldman \& Pentland, 2003; Thompson, 1967). A core definition of routines is that they comprise recognizable, repetitive patterns of interdependent actions by individuals within a given organization. Formal routines are complemented, and sometimes contrasted, by informal aspects that include beliefs, frameworks, paradigms, codes, cultures, and knowledge (Levitt \& March, 1988).

Scholars have debated the role of organizational routines, some contending that they are the means of organizational stability and continuity over time, leading towards organizational inertia (Foss, 2003; Nelson \& Winter, 1982), and others that they are dynamic, emerging systems that can foster organizational change and adaptation (Feldman, 2000; Levinthal, 1991). The present work adopts an evolutionary approach, focusing on routines as means of "learning", considering that they can sustain organizations in the effective storage, development and application of knowledge (Dyer \& Nobeoka, 2000; Levitt \& March, 1988).

Building on the thesis that learning is a history-dependent, routinebased, and target-oriented process (Levitt \& March, 1988), our research focuses on the concept of organizational learning as situated in social practices (Orlikowski, 2002) and built upon local practices and routines at the level of subgroups and teams (Edmondson, 2003). This derives from the idea that learning is dependent upon specific routines, which we may call adaptation routines (Nelson \& Winter, 1982).

Within the organization, routines are developed at different levels, starting with individuals, given that "... the essence of routines is that individuals develop sequential patterns of interaction which permit the integration of their specialized knowledge without the need for communicating that knowledge" (Grant, 1996, p. 379). At the team level, members develop routine arrangements to coordinate work - based on informal procedures and constant repetition, following explicit and implicit signals (Grant, 1996) - in which each applies specialist competences and knowledge, through automatic patterns of interaction (Dyer \& Nobeoka, 2000).

Adaptation routines are based on interdependencies among individual actions as interdependence allows people to communicate and coordinate in processes of collective learning and so to create new routines (Edmondson, 2003). These processes are intertwined in a learning ecology (Levitt \& March, 1988) or landscape (Prencipe \& Tell, 2001). The learning processes also form a knowledge cycle that allows organizations to capture experiential lessons through routines and make them available to other members, beyond those who had the direct experiences. Essential to this cycle is that routines be transmitted and experience interpreted, and that the organization have a shared, collective memory (Levitt \& March, 1988). The routine-based knowledge cycle links the sub-organizational levels and should foster organizational learning through learning within the sub-units (teams or projects), learning transmission between sub-units, and learning at the wider organization level (Scarbrough et al., 2004).

In order to account for the processes that occur at and between the various levels, we adopt the learning constructs proposed by Levitt and March (1988): (1) learning from direct experience and (2) learning from the experience of others, both of which occur at the individual level; (3) interpretation of experience, which occurs at the team level; (4) organizational memory, which is at the organizational level; and (5) ecologies of learning, which refer to inter-level analysis.

Building on these constructs, we extending previous research by using a multi-level framework of organizational learning, which allows a better understanding of (1) how actions in one part of the system - team members, teams or the organization - affect the evolution of routines elsewhere within the system and (2) how they affect the evolution of the system as a whole. This multi-level conceptual framework (see Fig. 1) allows the identification of patterns of variation, selection, and retention of actions, which in turn permits, through these patterns, the explanation of the dynamics of organizational routines and the analysis of the factors that influence them.

\section{Research setting and methods}

Among the Agile software development methods (Dingsøyr, Nerur, Balijepally, \& Moe, 2012), we focus specifically on scrum (Schwaber, 1997), a setting that is particularly suitable to inquire into the dynamics of organizational learning. The peculiarity of scrum is "empirical process control" with feedback loops on each action increment: team members coordinate their work with one member, the "scrum master", who mediates and moderates problems and issues. The teams are put under quite severe time pressure (see Behutiye, Rodríguez, Oivo, \& Tosun, 2017) and required to work on improvements, nurture additional process capabilities, respond to schedule changes, and migrate to new systems. This means that learning and innovation are essential elements (Highsmith, 2002).

We selected four R\&D organizations within a single multinational telecommunication company, through purposeful sampling (Patton, 1990). All organizations were experienced in Agile and strongly focused on learning processes. This company had transitioned from a bureaucratic structure to Agile software methodology - specifically, the scrum method (Schwaber, 2004) - for product development three years prior to the start of this analysis. The transition took two years and in the end involved all 1700 employees, in 90 different cross-functional teams.

Our sample embraced 79 teams working on the development of new software functions for complex, non-modular, and legacy systems. Specifically, the four organizations, which focused either on new product development and test consultancy or on system management activities, differed in terms of customers and product characteristics, as well as in the geographical distribution of activities (see Table 1 for details). The teams had an average of seven members, with diverse backgrounds and experiences in order to maximize cross-functional and cross-product capabilities.

This design allowed us to use replication logic (Eisenhardt, 1989), providing sufficient heterogeneity (Andriopoulos \& Lewis, 2009) while ensuring that participants were knowledgeable or experienced as regards specific phenomena (Creswell \& Plano Clark, 2011) and also capable of expressing opinions and describing their experiences articulately and thoughtfully.

Each team was rotated every six months between different activities and products. In this way, no team member would ever have exclusive control over any specific part of the work (Annosi, Magnusson, Martini, \& Appio, 2016). Interdependence among team members was favored by cross-functional work and the distribution of responsibilities; no member was accorded formal authority over peers. And the team as a whole was ultimately responsible for product releases and performance, encouraging regular discussion of status and processes. To develop the transition effectively, managers instilled a new set of core values into team members, with such components as continuous learning, knowledge sharing, product quality and organizational efficiency, and carried through a solid cultural transformation. Thus these organizations represented an excellent subject for studying the learning processes, allowing the observation of stable inter-team and variable intra-team factors, as well as individual characteristics (Annosi \& Brunetta, 2017).

We conducted a multiple case study; in view of the limited work on organizational learning in the literature on corporate agility, we adopted an abductive approach (Magnani, 2005). Following previous research (Eisenhardt, 1989), we selected cases that were theoretically relevant, gathered data, and then conducted our analysis. Moreover, the use of multiple case studies rather than a single case helped us to make findings that are more easily generalized and more broadly valid (Andriopoulos \& Lewis, 2009). 
LEVELS

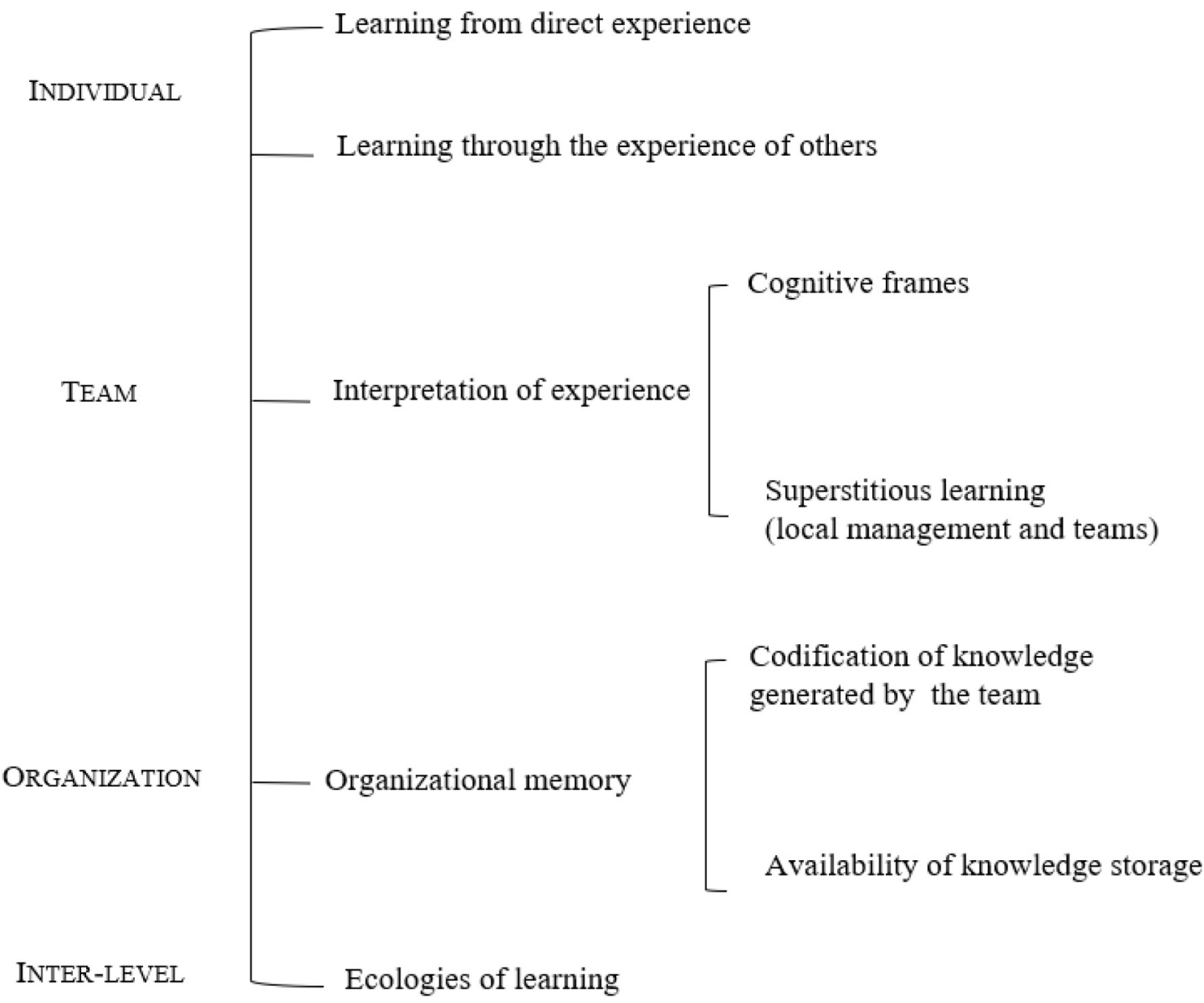

Fig. 1. Conceptual framework.

\subsection{Data collection}

The organizations examined made the transition to Agile in 2011; the transition was considered to be completed when all employees had been assigned to scrum teams (the end of 2012). Ninety teams were formed in the four R\&D organizations selected. We began our analysis one year after the completion of the transition. The data collection was extensive, exploiting (i) semi-structured interviews, (ii) free texts generated in an exploratory survey as secondary data sources, and (iii) archival data.
Researchers conducted 44 semi-structured interviews between August and October 2013 (41 interviews with the work teams and 3 with top-level managers; see Table 1). The interviewees included people in different Agile roles within the four R\&D organizations, and all roles were covered in the study. The focus of the interviews was the effects of the Agile concept on innovation and learning. An interview protocol was designed; the interviews lasted 60 to $80 \mathrm{~min}$ and were recorded, immediately transcribed and submitted to the interviewee for validation. A first round of interviews gathered information from diverse sub-groups, such as the main agile roles (scrum master, Agile

Table 1

Description of sampled organization.

\begin{tabular}{|c|c|c|c|c|c|c|}
\hline \multirow{2}{*}{ Organization } & \multirow{2}{*}{ Services } & \multirow{2}{*}{ Specialization } & \multirow{2}{*}{$\begin{array}{l}\text { No. of } \\
\text { Teams }\end{array}$} & \multirow{2}{*}{ Countries } & \multicolumn{2}{|r|}{ Interviewees } \\
\hline & & & & & No. & Level \\
\hline \multirow{3}{*}{$\mathbf{A}$} & \multirow{3}{*}{$\begin{array}{l}\text { New Product } \\
\text { Development, Testing }\end{array}$} & \multirow{3}{*}{$\begin{array}{l}\text { Mobile } \\
\text { Broadband }\end{array}$} & \multirow{3}{*}{20} & \multirow{3}{*}{$\begin{array}{l}\text { POL; CHN; } \\
\text { SWE }\end{array}$} & \multirow{3}{*}{11} & 1 top manager \\
\hline & & & & & & 7 middle managers \\
\hline & & & & & & 3 team members \\
\hline \multirow{3}{*}{ B } & \multirow{3}{*}{ System Management } & \multirow{3}{*}{ Radio Network } & \multirow{3}{*}{15} & \multirow{3}{*}{ SWE } & \multirow{3}{*}{8} & 1 top manager \\
\hline & & & & & & 4 middle managers \\
\hline & & & & & & 3 team members \\
\hline \multirow{3}{*}{ C } & \multirow{3}{*}{$\begin{array}{l}\text { New Product } \\
\text { Development, Testing }\end{array}$} & \multirow{3}{*}{$\begin{array}{l}\text { Radio Network; } \\
\text { Radio Base }\end{array}$} & \multirow{3}{*}{24} & \multirow{3}{*}{$\begin{array}{l}\text { POL; CHN; } \\
\text { SWE; IRL }\end{array}$} & \multirow{3}{*}{11} & 1 top manager \\
\hline & & & & & & 7 middle managers \\
\hline & & & & & & 3 team members \\
\hline \multirow{3}{*}{ D } & \multirow{3}{*}{$\begin{array}{l}\text { New Product } \\
\text { Development, Testing }\end{array}$} & \multirow{3}{*}{ Radio Network } & \multirow{3}{*}{20} & \multirow{3}{*}{ POL; SWE } & \multirow{3}{*}{11} & 1 top manager \\
\hline & & & & & & 7 middle managers \\
\hline & & & & & & 3 team members \\
\hline
\end{tabular}


team member or Product Owner), organizational entities (teams, individuals, supporting teams), and organizations (the four R\&D units). The method was stratified purposeful sampling. A second round of interviews was conducted with middle managers. Finally, a third round was conducted to settle informational questions that had arisen in the first two rounds.

As a secondary data source, we used 121 free text comments from an August 2013 survey of the four organizations, conducted in parallel with the interviews with team members, test consultants, product/, project/, program managers, and inquiring into the impact of the Agile method on adaptability, productivity, and quality.

Archival data, procured from informants, comprised such internal documents as web pages, general documents (e.g. continuous improvement frameworks, product improvement reports, Lean reports, Agile strategy reports, etc.), and R\&D documents (e.g. Agile amplifier for individual evaluations, competence goals, description of requirement areas, team development tools, etc.).

\subsection{Data analysis}

We began work on the separate case histories using the interviews, secondary and archival data (Eisenhardt, 1989). We reviewed meeting documents and materials, as well as internal planning and control sources, the content of information radiators and any reporting screens used by teams and management. We often discussed these materials during the interviews, giving the interviewees the opportunity to describe their work. We also discussed our observations with the head of the corporation. We focused on sketching out the organization's intentionality structures, first soliciting basic role descriptions from interviewees and then asking about the performance information that interviewees drew on or worked around in their daily activity. A triangulation was then made, taking account of issues emerging from the different data sources and confirmed by the interviewees (Jick, 1979). Two researchers reviewed the data separately, in order to develop independent interpretative frameworks.

\section{The results}

We describe the routines involved in the five learning-related constructs of Levitt \& March, 1988 (see Fig. 1): (1) learning from the team's direct experience, (2) learning through the experience of others, (3) interpretation of experience, including superstitious learning, (4) organizational memory, and (5) ecologies of learning. Each of these constructs is treated in a separate subsection below.

Learning from direct team experience and through the experience of others constitutes the processes by which knowledge is collected directly from team members. Interpretation of experience refers to the process whereby the information distributed is interpreted collectively by the teams. Organizational memory means the way in which cumulated knowledge is stored within the organization for future use. Ecologies of learning give information on the process by which information is shared within the organization in such a way as to generate new understanding.

\subsection{Learning from the team's direct experience (individual-level analysis)}

The modification of learning routines through direct experience may occur through either of two different mechanisms: organizational search and trial-and-error (Levitt \& March, 1988). Organizations that engage in experiential learning either through trial-and-error (Lindkvist, Bengtsson, Svensson, \& Wahlstedt, 2017) or search gradually adopt those routines if they lead to successful outcomes. However, the routines themselves are modified as the organization adapts and realizes which ones should be followed (Burgelman, 1988). As competences concerning the procedures used increase, the success rate improves, and consequently application of the procedures with the highest potential also increases.

Several team members in our sample voiced continuing concern about their difficulty of transcending the learning-by-doing approach, given the established working conditions derived from Agile. Even though managers encouraged members to consider ways to enhance their approach to learning, the latter did not seem able to shift from inertia to proactive learning.

Understanding the reason for the adoption and maintenance of such learning routines by team members is crucial to our aim of seeing how and why team learning is affected by the environment established with Agile. The interviews enabled us to trace the reason for their learning approach to the significance of the feedback loops instituted with scrum, which puts teams under strong pressure.

Asked how they managed activities within the Agile framework, the respondents spontaneously reported all the relevant details, so we could identify goal setting and feedback loops for teams and individuals alike. The main referents for team monitoring and goal setting were the external team stakeholders. Team monitoring was facilitated by the Agile framework and by the ceremonies and routines articulating work. The product owner dictated the team's tasks and the timetable for their accomplishment. Teams had to report to the product owners continuously concerning the status of their activities.

Apart from formal evaluations, teams were also pressed to update their daily work and make progress visible on the basis of the estimates made at the beginning of each sprint. All members had to present the results of their previous day's activities at a meeting (also involving their local stakeholders, such as the line managers and the product owners).

Teams focused strongly on feature development, which limited the time they could devote to learning and innovation. In fact, the large number of feedback loops made them see feature development as their top priority.

As we have seen, Agile team members adapt to experience in response to feedback about project outcomes. They monitor their behavior in terms of their project goals and engage in self-evaluation and reflection of their increasing effectiveness. Their learning behavior depends, then, on the relationship between observed project outcomes and their related aspirations. The learning routines that emerge therefore derive from members' interpretation of the past rather than anticipation of the future. Thus, as teams grow increasingly interconnected with their stakeholders and their work more and more closely integrated into the myriad feedback loops envisaged in scrum, they may not be effective in generating knowledge.

Teams also present a highly interconnected network of stakeholders, which in theory would appear to be better suited to the diffusion of the knowledge relevant for completing their task than to the generation of new knowledge in the fast-paced dynamics of Agile development iterations. The risk is that the diversity of the team's knowledge may diminish over time. These results suggest that team members may become too inwardly focused on deliveries and thus have trouble responding or adapting to the learning and innovation problem that has been detected.

Even though team members recognize the difficulty in embracing a method other than learning-by-doing, their understanding of organizational history, which mainly rewarded alignment with the project objectives, established conditions in which they could easily remain stuck in the old routines. This might mean they would fall into a competence trap (March, 1991), in which the experience of a good performance obtained with an inferior procedure makes it harder to reward a superior procedure (Levitt \& March, 1988). Competence traps can affect an organization's capacity to adapt, if the new routines are better than the old. They emphasize past experience and lead organizations to retain old routines even where they are not optimal. Table 2 displays the sample quotes. 
Table 2

Sample of quotes representing learning related constructs.

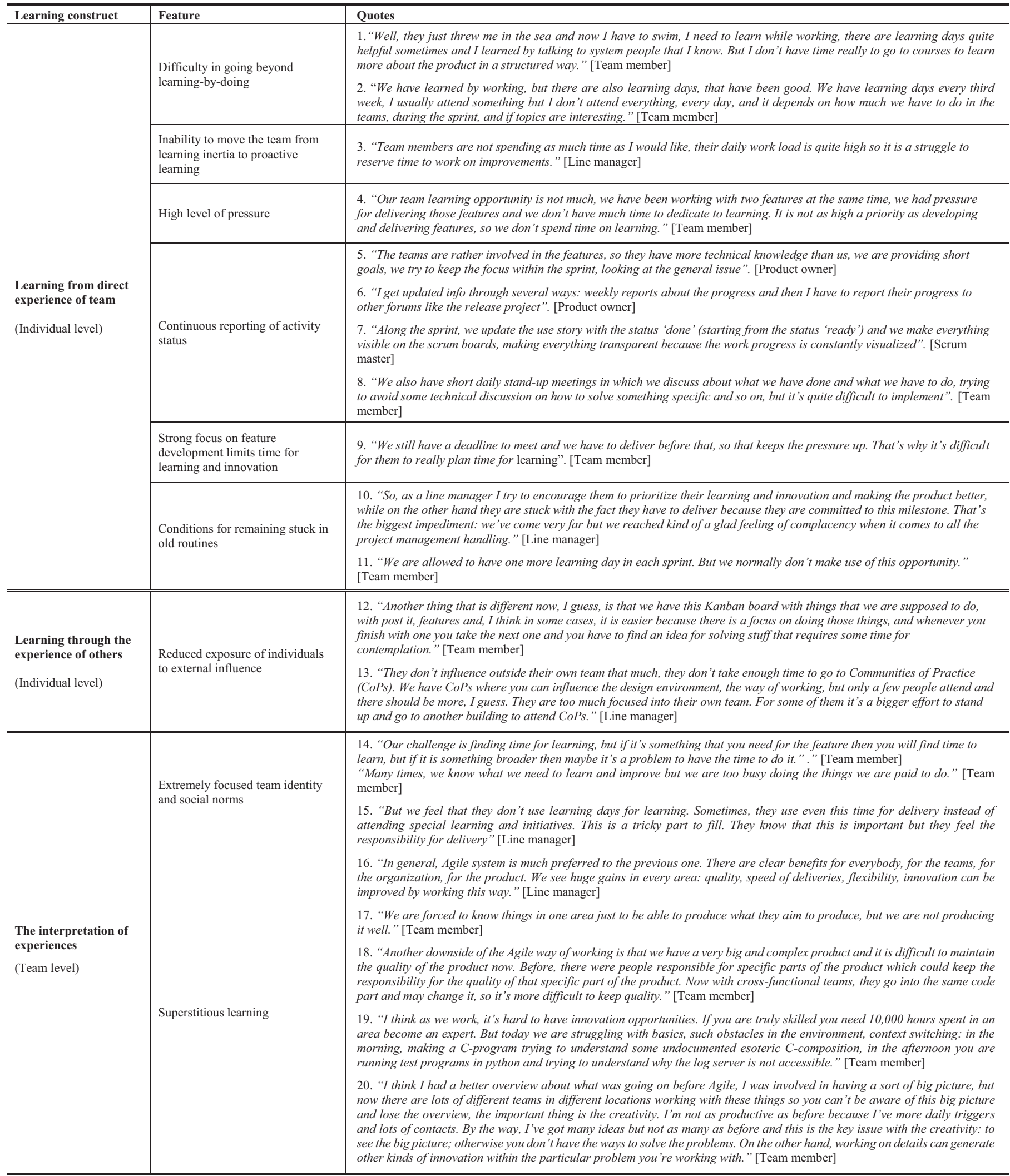




\begin{tabular}{|c|c|c|}
\hline \multirow{2}{*}{$\begin{array}{l}\text { The organizational } \\
\text { memory } \\
\text { (Organization level) }\end{array}$} & $\begin{array}{l}\text { Distinction between results } \\
\text { relevant and irrelevant to future } \\
\text { actions }\end{array}$ & $\begin{array}{l}\text { 21. "After the demo, the team gets together and does retrospective ceremony, looking back to the sprint and reflecting how to } \\
\text { improve ourselves. From each retrospective, we can have some action points to solve." [Team member] } \\
\text { 22. "At the end of the sprint we have a retrospective meeting in which we try to understand what we learn, what has been good } \\
\text { and bad; we highlight the item we would like to improve for the next sprint. It's about any kind of improvement: way of working, } \\
\text { design related, testing environment, quality of the product, productivity of our work, removing impediments we have". [Team } \\
\text { member] }\end{array}$ \\
\hline & $\begin{array}{l}\text { Inefficiency of CoPs in trasferring } \\
\text { relevant knowledge among } \\
\text { individuals }\end{array}$ & $\begin{array}{l}\text { 23. "Communities of Practice sometimes are useful and sometimes confusing, but I can't find a better way to do them. I attend } \\
\text { some of them, there are a lot of people, and sometimes we don't have so much discussion. Most CoPs are in a conference way." } \\
\text { [Team member] } \\
\text { 24. "I've been in some of the Communities of Practice. If we find topics that are interesting for us it's good to attend them. I } \\
\text { haven't been too active yet. I have the time to attend but mostly there weren't issues useful for my team's day by day work until } \\
\text { now. I'm a member of designer CoP. The participation depends on the period." [Team member] }\end{array}$ \\
\hline \multirow{3}{*}{$\begin{array}{l}\text { Ecologies of learning } \\
\text { (Inter level) }\end{array}$} & $\begin{array}{l}\text { Relevance of social problems (due } \\
\text { to interactions of actors having } \\
\text { different goals, intentions, } \\
\text { purposes, norms, and powers } \\
\text { within the teams and in the } \\
\text { organization) }\end{array}$ & $\begin{array}{l}\text { 25. "In the beginning it was more facilitation, but then as time went by, it's rare, actually, that they need my support that much, } \\
\text { because in the way we are set up now we have operative product owners, they're running the operation and most of the problems } \\
\text { teams have are related to operational issues, so it's more connected to soft aspects, like if people are not getting along in their } \\
\text { team so maybe we need to balance teams in a different way for competence reasons. Maybe we need to challenge them to give } \\
\text { us some impediments since they don't." [Line manager] }\end{array}$ \\
\hline & $\begin{array}{l}\text { Fragmentation, and construction, } \\
\text { of knowledge }\end{array}$ & $\begin{array}{l}\text { 26. "In the old way of working, you are familiar with the subsystem, and are aware of those changes, and have better control } \\
\text { of code. But now every team can modify code, and after a certain long period of time, you may not even recognize the subsystem. } \\
\text { In the old way of working, you are familiar with the subsystem, and are aware of those changes, and have better control of } \\
\text { code." [Team member] }\end{array}$ \\
\hline & $\begin{array}{l}\text { Team autonomy, in the sense that } \\
\text { teams continue operating in their } \\
\text { own way even in the absence of } \\
\text { any external intervention }\end{array}$ & $\begin{array}{l}\text { 27. "The line manager in the old way of working would kind be in the centre of the storm and get all the information and reports } \\
\text { and know all about the project. Now you must seek that info out if you want to find out about it, it doesn't come spontaneously. } \\
\text { I personally have a problem with that but I learned to live with it now and if I really want to find out about where we are, I } \\
\text { must look for people and ask them. On the other hand, I ask my team if they want project/product info and they indicate that } \\
\text { they don't need to get it every week so I try to balance that. The information flow is different, you have to seek the info out and } \\
\text { we do have these learning days where we got a lot of information to spread." [Line manager] }\end{array}$ \\
\hline
\end{tabular}

\subsection{Learning through the experience of others (individual-level analysis)}

Learning vicariously from the experience of others is a major channel for the diffusion of knowledge inside organizations. Vicarious learning usually implies the positive replication of routines, strategies and behaviors that have apparently been successful (Conell \& Cohn, 1995). Here we examine whether individuals learn from the success/ failure of other team members and/or members of the rest of the organization.

Vicarious learning can relate to various processes and phases: interteam near-failure or failure by peers that may induce an individual to seek out new activities; vicarious learning can provide a valuable source of knowledge, suggesting solutions or highlighting behavior to avoid or to imitate; and it can offer opportunities for strategy development (Kim \& Miner, 2000). Learning phenomena originating from direct experience can might happen vicariously through observation of the behaviors of other people and their conseqences (Bandura, 1986). Here the relevant concept is concertive control (Barker, 1993), i.e. the way in which team members, being observed by their peers, follow the established, legitimized rules of behavior.

The possibility of learning from others outside the teams, which depends on strong interdependence among peers, tends to be precluded by limited exposure of individuals to external influence. Greater interdependence of members within the team and their closeness and external exposure to other social influences create viable opportunities for individuals to learn vicariously from the learning and innovation efforts of other teams.

Team members, and consequently the entire team, may develop a cognitive model focusing on the reasons and methods for new combinations and knowledge creation within the team, by observing the learning activities of other team members who display some degree of learning inertia. This cognitive model, with its lack of proactive learning behavior, serves as guide for future search and provides insight into the approved learning routines that led to the generation of new knowledge within the team. Table 2 shows the sample quotes of the participants.

\subsection{The interpretation of experience (team-level analysis)}

People within organizations as well as members of a team tend to develop their interpretation of events, to label them as good or bad (Thompson, 1967). The interpretation of experience depends on how the events are framed (Daft \& Weick, 1984). Frames are “... composed of little tacit theories about what exists, what happens, and what matters" (Gitlin, 2003, p. 6) they make “... some aspects of a perceived reality more salient in a communicating text, in such a way as to promote a particular problem definition, causal interpretation, moral evaluation, and/or treatment recommendation" (Entman, 1993, p. 52). Frames are converted and developed using story lines that are to be shared (Martin, Sitkin, \& Boehm, 1985). This meaning structure is not a conscious concern, and learning takes place within it. In the long run, the organization will not abandon successful interpretive frames (Pettigrew, 1985).

There is a broad consensus in the literature that interpretative frames orient patterns of action and ground assumptions on how others will act in various contexts. The main interpretative frames associated with individual expectations are identity and norms as "social fact". These frames imply social approval and determine social influence over individual actions in various ways. As is evident from our interviews, team identity and social norms were focused very strictly on the need to deliver new software functions for the new development projects. Learning and innovation were not considered to be as important as coding. As Annosi et al. (2016) observe, in fact, pressure to "get the job done" is very common within Agile teams.

In self-managing teams, any dynamic structural change will be in accordance with the team's criteria for behavioral choices. In the regulation of teams' behavior, norms, identity and local culture become the key social forces that explain teams' learning inertia, with a lack of any strategy for overcoming issues of competence (Annosi et al., 2016). Thus, the establishment of identity and of norms that emphasize the need to deliver and to work cross-functionally, at team level, may impact on the long-term competence of team members and of the entire organization. 


\subsubsection{Superstitious learning}

The lessons of "experience" may stem from a small number of observations, in a changing and complicated ecology of learning and decentralized teams. What actually happened is not always clear, nor the causality of events easy to derive. People may tend to over-attribute situations to the intentions of individuals. They may apply simple linear and functional rules, engendering systematic biases in interpretation (Starbuck \& Milliken, 1988). What we call "superstitious learning" occurs when a subjective evaluation of success is not affected by the action taken (Levitt \& March, 1988). From this perspective, team members and leaders may assume the existence of causal relationships where they do not exist or interpret results in such a way as to serve their own interests. They may assume causal relationships between actions and environmental effects without considering alternative explanations or checking the validity of their interpretations (Levitt \& March, 1988).

The team managers in our study stressed the numerous benefits that would be brought by new Agile systems. They would provide better quality, shorter lead times and more innovative ideas, foster a more empowering climate among team members, and allow for better customer response.

The team members, however, considered Agile to be not so highly beneficial for the quality of the systems, in their experience, and although the Agile practices were officially encouraged, most team members judged that some corrections were necessary.

Another consequence of the difficulty of making Agile work was that team members often had serious difficulty in generating innovative ideas for their products - as if the transition to Agile had somehow resulted in a complete absence of creativity.

Although the team leaders responded positively to the introduction of Agile, team members saw it as a serious barrier to their individual innovation performance, not an enhancement of the way they conducted their work.

These findings indicate that a major strategic decision like the adoption of Agile methods can result in a considerable range of outcomes, to be identified and evaluated only through the assessment of organization members. The attention dedicated to these outcomes may be insufficient, and they can be evaluated by various parties with diverse viewpoints. Consequently, the managers involved in strategic decisions may not know the overall performance of their experience and so end up being unable to realize an effective learning process that generates correct future actions (Zollo, 2009). In this light, the accumulation of experience may have adverse effects, owing to the substantial uncertainties of performance assessment (Dönmez \& Grote, 2018). Once an organization slips into this loop, very commonly things only get worse. Quotes explaining this argument are reported in Table 2.

\subsection{The organizational memory (organizational-level analysis)}

The lessons of experience are gathered and retained within routines themselves. In this section, we examine whether team and inter-team routines are purposefully implemented in Agile to enable knowledge transfer across organizational boundaries. The routines of interest, that is, are those designed collectively within the teams and eventually transferred to the organization. The individual interviews offer relatively little insight into the ways in which teams cumulate their experience and build it into a structure of new routines. However, we do know that through the scrum routine of retrospective, team members try to think about the usefulness of their emergent behavior within the current sprint. Not everything is recorded in renewed routines for the next iteration of product development, only what proved to be successful vis-à-vis shared targets and aspirations. The collective reflection draws a distinction between the outcomes that will and those that will not be relevant for future action.

Through the retrospective meeting, the experiential knowledge acquired is recorded in the form of new rules or routines for the team. Looking at the way the network of teams is organized in Agile, we view Communities of Practice (CoPs) as mechanisms for facilitating the sharing of tacit knowledge useful to new routines. However, the interviews revealed a number of problems with knowledge sharing practices. The first problem is motivating self-interested individual team members to join the CoPs and share their acquired knowledge with their peers. The second problem is the difficulty in achieving collaboration among individual team members for common interests and goals. For instance, individuals may be willing to join the CoPs in order to acquire the desired knowledge but not to contribute to its development and maintenance. The third problem is making sure that the network of individuals is efficient at knowledge sharing and that the requisite pathways to facilitate the transfer of relevant knowledge among individuals are formed. Phrased more appropriately, the problem could be finding a way to achieve, through the CoPs, some necessary level of speed and easy access to the knowledge that is valuable. For instance, some types of knowledge may have been codified and others not.

If the CoPs only handle large group meetings, they are not likely to be efficient at transferring the relevant knowledge among individuals. All these issues emerged in the course of our interviews (see Table 2).

The quotes collected offer insights into the diffusion and evolution of new routines, moving from dyadic strong relationships within the teams to structures composed of weak ties, such as the CoPs. The interviewees' remarks also suggest that it takes time and greater managerial effort to foster relationship building and so facilitate the application and diffusion of new routines inside the Agile organization. We also find that internal relationships - those designed for learning by members within teams - have only a limited learning effect on interteam structures. In these conditions, Agile firms do not seem able to develop, over time, the capabilities needed to facilitate knowledge flows. Table 2 displays the sample quotes.

\subsection{Ecologies of learning (inter-level analysis)}

Organizations implementing Agile can be described as a collections of self-managing teams learning in an environment that consists of other learning teams. The resulting learning ecology has a high degree of complexity, owing to the relevance, in this context, of social problems for the interactions of the actors (who have different targets, powers, norms, purposes and intentions) with the teams and within the organization.

In addition, the presence of several self-managing teams working in parallel on the same part of the product introduces the problem of the fragmentation, and the construction, of knowledge. In Agile, no single actor or team can own all the knowledge required to solve a problem. Control and power too are fragmented.

The autonomy of a team is defined as the ability to continue to operate in its own way without external interference. To conclude, the role of formal authority is redesigned, so that governance and coordination appear to be the outcome of actions of networks, operating without any formal sanction.

Our findings point to difficulty in attaining optimal coordination of the development of new knowledge among teams in the product design network. The new knowledge generated is not made systematically available for teams in a way that allows them to use it to modify team practices. Change (learning) within the team depends on the extent of individuals' voluntary participation in network level learning activities. But individuals, then, must be willing to participate and knowledgeable enough to be able to share the knowledge. In short, the network structured around teams, knowledge and motivation for member participation becomes the pillar upon which the design of organizational learning in Agile is conceived and based. Currently, given the empirical evidence we collected, it would appear that organizational learning in Agile refers to changes in teams' processes/routines, based on the 
limited knowledge that the team, which is quite closed to external social influence, creates internally or can absorb, on its own, from external sources. Table 2 shows sample quotes.

\section{Multilevel evolution patterns}

Tables 3, 4, 5 and 6 summarize the results underlying the evolutionary dynamics of the routines involved in the five learning constructs (see Fig. 1). Applying evolution theory, we now discuss the results, centering on the same paradigm as evolution: periods of stability maintained by retention mechanisms, punctuated by elements of periodic change. These changes are created endogenously within a given level, or else exogenously imposed by the environment through the five learning constructs we considered in the multilevel framework. Each table explains the interrelationships of these two modes (equilibrium and revolution through the learning constructs). In this way we provide a new lens through which to obtain novel views of how individual skills affect organizational adaptation and how routines change within agile team-based organizations.

During the process of learning from direct experience (Table 3), variations - the creation of novel forms of routine - emerge systematically at individual level to improve the strategic fit with project goals and strategies, while routines for improving individual and team competences appear blind, the product of random individual choice (Table 3). At team level there is a selection of individual initiatives to foster the fit with the resource base of the development project. At organization level, agile routines provide the means for counteracting the self-reinforcing loop between variation at individual level and selection at team level (see Table 3). Our preliminary results contradict such previous agile literature as Plonka (1997), Prahalad and Hamel (1990) and Yusuf, Sarhadi, and Gunasekaran (1999), all of which instead emphasize the positive effect of agile on individual competences.

Regarding the construct of learning through the experience of others (Table 4), we can maintain that, collectively, teams produce small variations in the routines they follow, and only in order to achieve their project goals more easily. The formation of collective behavior and mind-set within the team is due to the formation of team identity and norms. Through a process of individual identification with the team, individuals choose only behavioral strategies that lead them to embrace the team's goals. At the organizational level, the bottom-up effort to achieve project goals and the investment of energies in attaining project objectives create a local culture centering on the successful performance of project tasks and with strong resistance to change in team members' priorities. Earlier works on Agile, without examining the key Agile concepts and underlying relationships empirically, argue instead that Agile tends to create a slightly chaotic environment that favors innovation and creativity (Highsmith, 2002).

Table 5, summarizing the results derived from the learning construct of cognitive frames, shows that the team identity constitutes, for the team, a sort of punctuated equilibrium around which behavior fluctuates quite modestly. The consequent team identification affects individual cognition, motivation and obligation, which are the three main barriers to radical change in human systems (e.g. Tushman \& Romanelli, 1985). However, as Tushman and Romanelli (1985: 177) argue, even as a system transcends its motivational and cognitive barriers to realize change, the "network of interdependent resource relationships and value commitment" created by organizational routines can affect its attitude towards change. So organizational routines, including the complex set of an agile team's stakeholders, create conditions of stability for the team identity that has emerged. On the other hand, individuals cannot select behavior other than that which is legitimated by the team, since they benefit from its persistence, which enables them to pursue goals and accomplish their tasks (Gersick, 1991). Past agile literature presents this organizational approach as highly desirable, guaranteeing satisfaction, turnaround, shared learning and productivity. Unfortunately, little work has addressed the impact of agile on such long-term organizational goals as innovation and learning (Abrahamsson et al., 2009).

Tables 3, 4 and 5 help to clarify why incremental changes within one part of an organization - the individual, the team, the organization - may fail to alter the whole. We have shown that as long as the agile scrum structure remains intact, the implementation of agile creates powerful inertia, reducing the organization's capability to produce alternatives outside the development project goals, and bringing any deviation back into line. Table 6 then shows how the agile scrum framework leaves the team temporarily disorganized during the retrospective meeting, whose function is to make fundamental changes for the development project. However, the weak interdependency between

Table 3

Organizational adaptation due to learning from direct experience.

\begin{tabular}{|c|c|}
\hline Intra-level dynamics & Evolution patterns \\
\hline \multirow{2}{*}{$\begin{array}{l}\text { Our findings led us away from the idea that individuals strive to generate } \\
\text { alternative configurations of their working activities so as to improve their } \\
\text { product learning performance. Variation generally tends towards the goal of } \\
\text { anticipating stakeholders' needs, which are mostly directed to new project } \\
\text { development. }\end{array}$} & \multirow{5}{*}{$\begin{array}{l}\text { Low degree of variation to improve } \\
\text { individual product competence } \\
\text { High effort in the generation of variation in } \\
\text { daily individual practices to improve team's } \\
\text { performance in achieving project goals } \\
\text { No selection of any alternative idea for } \\
\text { improvement of their product learning } \\
\text { performances } \\
\text { Selection of ideas for improving team's } \\
\text { performances in terms of reduced lead time } \\
\text { and better product quality }\end{array}$} \\
\hline & \\
\hline \multirow{3}{*}{$\begin{array}{l}\text { Agile teams were all challenged to improve their productivity and the quality } \\
\text { of their outcomes, by experimenting with new ways of working effectively } \\
\text { together and dealing with Agile stakeholders expectations, and pacing } \\
\text { themselves to meet the project deadline. Therefore, with a strong identity } \\
\text { oriented to new product development, as a collective, they were less inclined to } \\
\text { select any individual proposal that went in a different direction from } \\
\text { achievement of short-term project goals. }\end{array}$} & \\
\hline & \\
\hline & \\
\hline $\begin{array}{l}\text { The Agile scrum routines, designed to monitor individual performance, create } \\
\text { a set of distinct and historically sequenced steps that dominate individual } \\
\text { learning behaviour. With the constant replication of Agile routines in team } \\
\text { members' daily working lives, the Agile organization creates a retention } \\
\text { mechanism; the routines forge a pattern of convergence and re-orientation of } \\
\text { individual behaviour }\end{array}$ & $\begin{array}{l}\text { Agile organization routines act as replication } \\
\text { mechanisms for retaining the alignment of } \\
\text { individual behaviour to the project } \\
\text { development goals }\end{array}$ \\
\hline
\end{tabular}

According to Plonka (1997), instead, Agile fosters individual learning through proactive, adaptive, and generative behavior. Specifically, Prahalad and Hamel (1990) and Yusuf et al. (1999) argue that the Agile workforce capitalizes on skills by proactively renewing their skill base just ahead of need 
Table 4

Organizational adaptation due to learning from others.

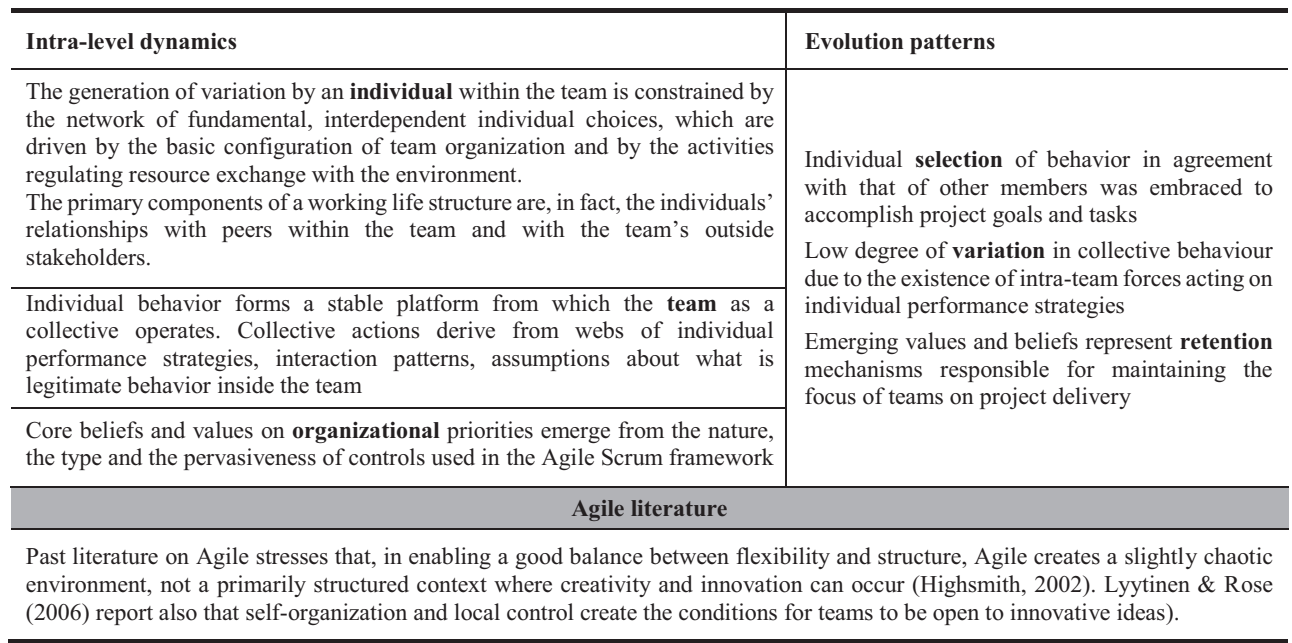

Table 5

Organizational adaptation due to interpretation of experience.

\begin{tabular}{|c|c|}
\hline Intra-level dynamics & Evolution patterns \\
\hline $\begin{array}{l}\text { The primary task of individuals in teams is to make a set of key choices, pursue } \\
\text { their goals and respect their values. Whenever a team identity is formed, distinctive } \\
\text { tasks take form and tend to remain stable. }\end{array}$ & \multirow{3}{*}{$\begin{array}{l}\text { Individual selection of behavior to } \\
\text { conform with the current team identity } \\
\text { Low degree of variation in collective } \\
\text { behaviour due to the existence of stable } \\
\text { team identity and norms } \\
\text { Incremental change in the direction of } \\
\text { accomplishing project goals }\end{array}$} \\
\hline $\begin{array}{l}\text { During a phase of stable team identity, teams tend to accumulate more or less } \\
\text { learning, experience, work within the boundaries established by their identity, and } \\
\text { to apply stable frameworks of assumptions, premises and behavior patterns } \\
\text { (Gersick, 1988) }\end{array}$ & \\
\hline $\begin{array}{l}\text { At the organization level, incremental change in structures, system and control, } \\
\text { which appear to lead to some inertia and a decrease in competitive vigilance. In the } \\
\text { case of Agile, structure was driving strategy (Tushman \& Romanelli 1985) }\end{array}$ & \\
\hline Agile literature & \\
\hline
\end{tabular}

Studies on post-adoption Agile are very few indeed. Cockburn \& Williams (2001) describe the Agile benefits as increased productivity, faster turnaround, shared learning, and greater developer satisfaction. Goldman et al. (1995) list productivity, profits and market shares as the organizational benefits deriving from workforce agility. Gehani (1995) links workforce agility with enhancement of organizations' prospects for survival in more and more rapidly changing environments. More in general, the literature proposes the adoption of Agile as universally desirable, without looking at its differential impact on the distinct dimensions of development performance (Xia \& Weidgon, 2010) or devoting significant attention to the Agile post-adoption phase.

Table 6

Organizational adaption due to organizational memory and ecologies of learning.

\begin{tabular}{|c|c|}
\hline Intra-level dynamics & Evolution patterns \\
\hline $\begin{array}{l}\text { As a primary task, individuals on teams are called to reappraise the existing structure, } \\
\text { to explore possibilities for change, and to move towards the crucial choice of } \\
\text { implementing the changes accepted as the basis for a new routine. }\end{array}$ & \multirow{5}{*}{$\begin{array}{l}\text { Variation in the proposals to change } \\
\text { Strong selection of ideas of change due } \\
\text { to the existence of stable team identity and norms } \\
\text { No selection of new variation due to the } \\
\text { coordination of information between teams }\end{array}$} \\
\hline $\begin{array}{l}\text { The retrospective provides a compact, time-limited possibility of breaking out of the } \\
\text { team's inertia. During that time, team members offer their new ideas on how to } \\
\text { improve the way of working in order to better accomplish the stakeholders' needs. }\end{array}$ & \\
\hline \multirow{2}{*}{$\begin{array}{l}\text { However, the retrospective does not involve change in team core values, which } \\
\text { instead govern general core premises. Therefore, it does not represent a radical form } \\
\text { of re-orientation }\end{array}$} & \\
\hline & \\
\hline $\begin{array}{l}\text { Potentially, retrospectives represent short periods of discontinuous change, where } \\
\text { teams may be fundamentally transformed, instituting a new basis of alignment. } \\
\text { However, the system of relations between teams, through the Communities of } \\
\text { Practices, is too weak to sustain adequate diffusion of information, which results in } \\
\text { the organization's failing to find a new global configuration }\end{array}$ & \\
\hline Agile literature & \\
\hline
\end{tabular}

The Agile workforce is said to gain from collaboration, both within and outside the organization (Goldman \& Nagel, 1993; Gunasekaram, 1999). It is argued that Agile workforces act flexibly, rapidly and effectively in any collaboration environment (Forsythe, 1997) 
Table 7

Routines involved in the five learning related constructs of Levitt and March (1988) and implications for managers.

\begin{tabular}{|c|c|c|}
\hline Learning construct & Routines involved & Implications \\
\hline \multirow{4}{*}{$\begin{array}{l}\text { Learning from team's direct } \\
\text { experience (individual level) }\end{array}$} & Visible progress on project-related tasks & Managers can affect learning from team's direct experience both by \\
\hline & Daily updates from team members & reducing the number of project feedback loops and by adding new \\
\hline & $\begin{array}{l}\text { After-sprint reflection on how to further improve teams' project } \\
\text { performance }\end{array}$ & team feedback loops to reinforce team and individual competences \\
\hline & $\begin{array}{l}\text { Strong interconnection with project stakeholders through scrum } \\
\text { ceremonies }\end{array}$ & $\begin{array}{l}\text { Managers can affect learning from teams' direct experience by } \\
\text { creating routines through which interactions with other stakeholders } \\
\text { can take shape, to balance teams' attention between project-related } \\
\text { and other goals }\end{array}$ \\
\hline $\begin{array}{l}\text { Learning through the experience } \\
\text { of others (individual level) }\end{array}$ & $\begin{array}{l}\text { High level of interdependency among team members, accentuated } \\
\text { by cross-functional tasks }\end{array}$ & $\begin{array}{l}\text { Managers can impact on vicarious learning through others' } \\
\text { experience by reducing interdependency among team members, } \\
\text { either by acting on the way the teams' tasks are shared or by reducing } \\
\text { knowledge overlap among members }\end{array}$ \\
\hline \multirow[t]{3}{*}{$\begin{array}{l}\text { The interpretation of experience } \\
\text { (team level) }\end{array}$} & Team norms stuck on the need to get the job done & $\begin{array}{l}\text { Managers can affect teams' interpretation of experience by acting on } \\
\text { team norms that in turn derive from the intensity of the feedback } \\
\text { loops/routines that create the need for continuous reporting of the } \\
\text { status of work progress and by increasing the salience of the } \\
\text { information to report }\end{array}$ \\
\hline & Superstitious learning & \\
\hline & $\begin{array}{l}\text { Lack of inter-level routines to collect information about the effect of } \\
\text { Agile Scrum on employees' work life and their perception of } \\
\text { performances }\end{array}$ & $\begin{array}{l}\text { Managers can reduce superstitious learning by creating routines for } \\
\text { regularly analyzing the status of implementation of Agile practices }\end{array}$ \\
\hline \multirow[t]{2}{*}{$\begin{array}{l}\text { Organizational memory } \\
\text { (organization level) }\end{array}$} & $\begin{array}{l}\text { Possibility of renewing organizational routines in Agile is strictly } \\
\text { linked to teams' collective targets and aspirations }\end{array}$ & $\begin{array}{l}\text { Managers can affect organizational memory by intervening on teams' } \\
\text { collective targets and aspirations }\end{array}$ \\
\hline & $\begin{array}{l}\text { Communities of practices, as a means of diffusing emerging } \\
\text { knowledge and experience to other teams, do not have embedded } \\
\text { mechanisms for long-run survival }\end{array}$ & $\begin{array}{l}\text { Managers can affect organizational learning by enhancing the design } \\
\text { of their CoPs. Stronger linkages between team members and CoP } \\
\text { leaders should be forged, so as to strengthen individuals' belief in the } \\
\text { importance of taking part in the CoP activities }\end{array}$ \\
\hline Ecologies of learning (inter-level) & $\begin{array}{l}\text { Lack of routines for transforming the knowledge developed at team } \\
\text { level from tacit into explicit or for aggregating teams' knowledge at } \\
\text { organization level. The volatile nature of knowledge seems to justify } \\
\text { the lack of knowledge coordination among Agile managers }\end{array}$ & $\begin{array}{l}\text { Managers can affect the ecologies of learning by creating mechanisms } \\
\text { for aggregating the decentralized sources of newly developed } \\
\text { knowledge in order to make it accessible to everyone within the } \\
\text { organization }\end{array}$ \\
\hline
\end{tabular}

the agile teams through CoPs and the strongly independent character of each team's work make it clear that the changes introduced can quickly hit a dead end. The existing agile literature suggests that the workforce can gain from collaborating, both inside and outside the organization (Goldman \& Nagel, 1993; Gunasekaran, 1999), but it does not prescribe efficient means whereby such collaboration can help the entire organizational system to evolve.

\section{Conclusions and managerial implications}

We use evolution theory to focus on cumulative changes in organizational routines at all levels of the organization. Following the scholarly debate on the need for empirical validation of the core agile concepts and their relationships in order to make them more solid (Boehm \& Turner, 2004; Larman, 2004), we have taken evolution theory here as an overarching framework for studying the adaptation capacity of agile organizations. And in view of the lack of systematic knowledge on the dynamics of routines and the interactions between individual and organizational learning (Yi et al., 2016), we have sought to fill the serious research gap on routines and organizational adaptation.

This article should help scholars and practitioners to go beyond simply labelling agile as the organizational solution for learning and innovation. It is important for practitioners to be aware that the prescription that agile enables learning is not universal. Agile organizations are complex systems; they are influenced and constrained by a network of stakeholders and routines that may introduce conflicting demands and opposing perspectives. Our more precise examination of the micro-processes of organizational adaptation within agile corporations based on self-managed teams reveals the crucial tension between the organization's project development goals and the need to transcend contingent requests and further the renewal of key individual competences and organizational routines. Through a deeper understanding of the micro-mechanisms involved in learning processes within self- managing teams, that is, we have sought to indicate how the notion of organizational leadership without control can apply in the agile context. The immediate implications for managers, who have the day-today responsibility for the performance of teams and individuals, are thus readily associated with predictable changes in the organizational design and structure. These implications are summarized in Table 7.

The most important implication is that managers can actively influence the significance of team priorities and how they respond to the organizational goal of learning. Shifting away from the idea that organizational learning and adaptation proceed towards unforeseeable outcomes, given the evolving forces of emerging social interactions, we propose that carefully designed and maintained processes and linkages will provide the basis for organizational leadership without control, within new forms of organization. We have shown that the intangible qualities of vision, culture, and shared values in decentralized structures such as agile teams depend chiefly on the specific characteristics of the organizational configurations.

This suggests that the management of agile organizations should be instrumental in achieving congruence between a set of team attributes and a set of organizational characteristics. Adopting some of assumptions set out in Table 7 , the congruence approach is extended to concrete configurational models.

Without making current organizational structure any more complex, leaders should apply flexibility-injecting structures, such as additional stakeholders and goals for agile teams, to help strike the right balance between flexibility and efficiency (Dönmez, Grote, \& Brusoni, 2016). We accordingly contend that in implementing agile routines, corporate leaders must ensure the coexistence of potentially conflicting solutions (Martini, Gastaldi, Corso, \& Laugen, 2013; Smith \& Tushman, 2005).

Our theoretical approach highlights some new areas for future research. We expect further research to analyze the way in which different contextual and organizational factors can moderate the effect of agile scrum implementation on organizational adaptation and survival. Relevant factors could be industry structure and competition, the 
essential dimension of organizational design, and the extent of change in the environment or technology.

The state of our knowledge about the interdependence between organizational configurations and organizational adaptability to the introduction of agile scrum practices is now advanced enough to permit a more systematic effort to develop further understanding, new theoretical frameworks and research on new organizational forms and to raise new questions about agile as the new, evolving organizational paradigm.

Recognizing the key role of leadership without control in agile organizational change, our multi-level analysis of leadership identified a variety of broad strategies, implemented through various organizational configurations. Thus, whereas some other authors have described leaders as guiding the delegitimation of the old ways of working and legitimating the organizational change desired (Pettigrew, 1987), heading a dominant political process (Bower \& Weinberg, 1988), creating a new organizational culture and new values (Sashkin, 1992), or instilling vision and empowerment or energizing, members (Nadler \& Tushman, 1990), we conceive the position of leaders in the new organizational forms as relating to the design of coherent organizational configurations.

Interesting questions that could still be raised from the configurational standpoint include the degree to which these configurations can be generalized to other organizational contexts and the way in which different organizational configurations may be associated with other leadership traits.

We believe that addressing such configurational questions can help to advance the search for new organizational forms beyond our current understanding. This suggests that incorporating configurations into the theory of new organizational forms could help to define the impact of the new paradigms on organizational capability to adapt.

\section{References}

Abell, P., Felin, T., \& Foss, N. (2008). Building micro-foundations for the routines, capabilities, and performance links. Managerial and Decision Economics, 29(6), 489-502.

Abrahamsson, P., Conboy, K., \& Wang, X. (2009). 'Lots done, more to do': The current state of agile systems development research. European Journal of Information Systems, 18(4), 281.

Aldrich, H. (1999). Organizations evolving. Sage.

Andriopoulos, C., \& Lewis, M. W. (2009). Exploitation-exploration tensions and organizational ambidexterity: Managing paradoxes of innovation. Organization Science, 20(4), 696-717.

Annosi, M. C., \& Brunetta, F. (2017). New organizational forms, controls, and institutions: Understanding the tensions in 'Post-Bureaucratic' Organizations. Springer.

Annosi, M. C., \& Brunetta, F. (2018). Resolving the dilemma between team autonomy and control in a post-bureaucratic era. Organizational dynamics. (Forthcoming).

Annosi, M. C., Foss, N., Brunetta, F., \& Magnusson, M. (2017). The interaction of control systems and stakeholder networks in shaping the identities of self-managed teams. Organization Studies, 38(5), 619-645.

Annosi, M. C., Magnusson, M., Martini, A., \& Appio, F. P. (2016). Social conduct, learning and innovation: An abductive study of the dark side of agile software development. Creativity and Innovation Management, 25(4), 515-535.

Argote, L., \& Ingram, P. (2000). Knowledge transfer: A basis for competitive advantage in firms. Organizational Behavior and Human Decision Processes, 82(1), 150-169.

Argote, L., \& Miron-Spektor, E. (2011). Organizational learning: From experience to knowledge. Organization Science, 22(5), 1123-1137.

Avolio, B. J., Walumbwa, F. O., \& Weber, T. J. (2009). Leadership: Current theories, research, and future directions. Annual Review of Psychology, 60, 421-449.

Bandura, A. (1986). The explanatory and predictive scope of self-efficacy theory. Journal of Social and Clinical Psychology, 4(3), 359-373.

Barker, J. R. (1993). Tightening the iron cage: Concertive control in self-managing teams. Administrative Science Quarterly, 38(3), 408-437.

Bartlett, C. G., \& Ghoshal, S. S. (1989). Managing across borders: The transnational solution. Boston, MA: Harvard Business School Press.

Behutiye, W. N., Rodríguez, P., Oivo, M., \& Tosun, A. (2017). Analyzing the concept of technical debt in the context of agile software development: A systematic literature review. Information and Software Technology, 82, 139-158.

Betsch, T., Haberstroh, S., \& Hohle, C. (2002). Explaining routinized decision making: A review of theories and models. Theory \& Psychology, 12(4), 453-488.

Boehm, B., \& Turner, R. (2004, May). Balancing agility and discipline: Evaluating and integrating agile and plan-driven methods. Software engineering, 2004. ICSE 2004. Proceedings. 26th international conference on (pp. 718-719). IEEE.

Bower, J. L., \& Weinberg, M. W. (1988). Statecraft, strategy, and corporate leadership. California Management Review, 30(2), 39-56.
Burgelman, R. A. (1988). Strategy making as a social learning process: The case of internal corporate venturing. Interfaces, 18(3), 74-85.

Campbell, D. T. (1990). Levels of organization, downward causation, and the selectiontheory approach to evolutionary epistemology. In G. Greenberg, \& E. Tobach (Eds.). Theories of the evolution of knowing (pp. 1-17). Hillsdale, NJ: Lawrence Erlbaum Associates, Inc.

Cohen, M. D., Burkhart, R., Dosi, G., Egidi, M., Marengo, L., Warglien, M., \& Winter, S. (1996). Routines and other recurring action patterns of organizations: Contemporary research issues. Industrial and Corporate Change, 5(3), 653-698.

Conell, C., \& Cohn, S. (1995). Learning from other people's actions: Environmental variation and diffusion in French coal mining strikes, 1890-1935. American Journal of Sociology, 101(2), 366-403.

Creswell, J. W., \& Plano Clark, V. (2011). Collecting data in mixed methods research. Designing and conducting mixed methods research (pp. 171-202). Thousand Oaks, CA: Sage Publications.

Crossan, M., Maurer, C., \& White, R. (2013). Multilevel mechanisms of organizational learning. International conference on organizational learning, knowledge and capabilities, April, Washington, USA.

Daft, R. L., \& Lewin, A. Y. (1993). Where are the theories for the "new" organizational forms? An editorial essay. Organization Science, $i-v i$.

Daft, R. L., \& Weick, K. E. (1984). Toward a model of organizations as interpretation systems. Academy of Management Review, 9(2), 284-295.

Dingsøyr, T., Nerur, S., Balijepally, V., \& Moe, N. B. (2012). A decade of agile methodologies: Towards explaining agile software development. The Journal of Systems \& Software, 6(85), 1213-1221.

Dönmez, D., \& Grote, G. (2018). Two sides of the same coin-how agile software development teams approach uncertainty as threats and opportunities. Information and Software Technology. 93(1), 94-111.

Dönmez, D., Grote, G., \& Brusoni, S. (2016). Routine interdependencies as a source of stability and flexibility. A study of agile software development teams. Information and Organization, 26(3), 63-83.

Dyer, J. H., \& Nobeoka, K. (2000). Creating and managing a high-performance knowledge-sharing network: The Toyota case. Strategic Management Journal, 21(3), 345-367.

Dyer, L., \& Shafer, R. A. (2003). Dynamic organizations: Achieving marketplace and organizational agility with people. CAHRS working paper series: 27.

Edmondson, A. C. (2003). Speaking up in the operating room: How team leaders promote learning in interdisciplinary action teams. Journal of Management Studies, 40(6), 1419-1452.

Eisenhardt, K. M. (1989). Agency theory: An assessment and review. Academy of Management Review, 14(1), 57-74.

Entman, R. M. (1993). Framing: Toward clarification of a fractured paradigm. Journal of Communication, 43(4), 51-58.

Feldman, M. S. (2000). Organizational routines as a source of continuous change. Organization Science, 11(6), 611-629.

Feldman, M. S., \& Pentland, B. T. (2003). Reconceptualizing organizational routines as a source of flexibility and change. Administrative Science Quarterly, 48(1), 94-118.

Fiol, C. M., \& Lyles, M. A. (1985). Organizational learning. Academy of Management Review, 10(4), 803-813.

Foss, N. J. (2003). Bounded rationality and tacit knowledge in the organizational capabilities approach: An assessment and a re-evaluation. Industrial and Corporate Change, 12(2), 185-201.

Gersick, C. J. (1991). Revolutionary change theories: A multilevel exploration of the punctuated equilibrium paradigm. Academy of Management Review, 16(1), 10-36.

Gitlin, T. (2003). The whole world is watching: Mass media in the making and unmaking of the new left. Univ of California Press.

Goldman, S. L., \& Nagel, R. N. (1993). Management, technology and agility: The emergence of a new era in manufacturing. International Journal of Technology Management, $8(1-2), 18-38$.

Grant, R. M. (1996). Toward a knowledge-based theory of the firm. Strategic Management Journal, 17(S2), 109-122.

Greve, H. R. (2008). A behavioral theory of firm growth: Sequential attention to size and performance goals. Academy of Management Journal, 51(3), 476-494.

Gunasekaran, A. (1999). Agile manufacturing: A framework for research and development. International Journal of Production Economics, 62(1-2), 87-105.

Hazy, J. K., \& Uhl-Bien, M. (2013). Changing the rules: The implications of complexity science for leadership research and practice. Oxford Handbook of Leadership and Organizations.

Highsmith, J. A. (2002). Agile software development ecosystems (Vol. 13). Addison-Wesley Professional.

Hodgson, G. M. (2008). The concept of a routine. Handbook of organizational routines. 15.

Jick, T. D. (1979). Mixing qualitative and quantitative methods: Triangulation in action. Administrative Science Quarterly, 24(4), 602-611.

Kim, J. Y. J., \& Miner, A. S. (2000). Crash test without dummies: A longitudinal study of interorganizational learning from failure experience in the US commercial banking industry, 1984-1998. Academy of Management Proceedings, 2000(1), G1-G6 (Academy of Management).

Larman, C. (2004). Agile and iterative development: A manager's guide. Addison-Wesley Professional.

Levinthal, D. A. (1991). Random walks and organizational mortality. Administrative Science Quarterly, 36(3), 397-420.

Levitt, B., \& March, J. G. (1988). Organizational learning. Annual Review of Sociology, 14(1), 319-338.

Lindkvist, L., Bengtsson, M., Svensson, D. M., \& Wahlstedt, L. (2017). Replacing old routines: How Ericsson software developers and managers learned to become Agile. Industrial and Corporate Change, 26(4), 571-591. 
Magnani, L. (2005). An abductive theory of scientific reasoning. Semiotica, 2005(153-1/ 4), 261-286

March, J. G. (1991). Exploration and exploitation in organizational learning. Organization Science, 2(1), 71-87.

Martin, J., Sitkin, S. B., \& Boehm, M. (1985). Founders and the elusiveness of a cultural legacy. In P. J. Frost, L. F. Moore, M. R. Louis, C. C. Lundberg, \& J. Martin (Eds.). Organisational culture.

Martini, A., Gastaldi, L., Corso, M., \& Laugen, B. (2013). Continuous innovation: Towards a paradoxical, ambidextrous combination of exploration and exploitation. International Journal of Technology Management, 61, 1-22.

Miles, R. E., \& Snow, C. C. (1986). Organizations: New concepts for new forms. California Management Review, 28(3), 62-73.

Moe, N. B. (2013, June). Key challenges of improving agile teamwork. nternational Conference on Agile Software Development (pp. 76-90). Berlin, Heidelberg: Springer.

Morris, S. A., \& McManus, D. J. (2006). Information infrastructure centrality in the agile organization. Information Systems Management, 19(4), 8-12.

Nadler, D. A., \& Tushman, M. L. (1990). Beyond the charismatic leader: Leadership and organizational change. California Management Review, 32(2), 77-97.

Nagel, R. N., \& Dove, R. (1991). 21st century manufacturing enterprise strategy: An industryled view. Diane Publishing.

Nelson, R. R., \& Winter, S. G. (1982). An evolutionary theory of economic change. Cambridge, MA: Belknap Press.

Nelson, R. R., \& Winter, S. G. (2002). Evolutionary theorizing in economics. Journal of Economic Perspectives, 16(2), 23-46.

Orlikowski, W. J. (2002). Knowing in practice: Enacting a collective capability in distributed organizing. Organization Science, 13(3), 249-273.

Patton, M. Q. (1990). Qualitative evaluation and research methods. SAGE Publications.

Peruffo, E., Marchegiani, L., \& Vicentini, F. (2018). Experience as a source of knowledge in divestiture decisions: Emerging issues and knowledge management implications. Journal of Knowledge Management, 22(2), 344-361.

Pettigrew, A. (1985). The awakening giant: Continuity and change in Imperial Chemical Industries. Wiley-Blackwell.

Pettigrew, A. M. (1987). Context and action in the transformation of the firm. Journal of Management Studies, 24(6), 649-670.

Plonka, F. E. (1997). Developing a lean and agile work force. Human Factors and Ergonomics in Manufacturing \& Service Industries, 7(1), 11-20.

Prahalad, C., \& Hamel, G. (1990). The core competence of the corporation. Harvard Business Review, 68(3), 79-91.

Prencipe, A., \& Tell, F. (2001). Inter-project learning: Processes and outcomes of knowledge codification in project-based firms. Research Policy, 30(9), 1373-1394.

Salvato, C., \& Rerup, C. (2011). Beyond collective entities: Multilevel research on organizational routines and capabilities. Journal of Management, 37(2), 468-490.

Sashkin, M. (1992). Strategic leadership competencies. In R. L. Phillips, \& J. G. Hunt (Eds.). Strategic Leadership (pp. 139-160). Westport, CT: Quorum Books.

Scarbrough, H., Swan, J., Laurent, S., Bresnen, M., Edelman, L., \& Newell, S. (2004). Project-based learning and the role of learning boundaries. Organization Studies, 25(9), 1579-1600.

Schwaber, K. (1997). Scrum development process. Business object design and implementation (pp. 117-134). London: Springer.
Schwaber, K. (2004). Agile project management with scrum. Microsoft press.

Schwaber, K., \& Beedle, M. (2002). Agile software development with Scrum. 1. Upper Saddle River: Prentice Hall.

Senapathi, M., \& Srinivasan, A. (2012). Understanding post-adoptive agile usage: An exploratory cross-case analysis. Journal of Systems and Software, 85(6), 1255-1268.

Shippmann, J. S., Ash, R. A., Batjtsta, M., Carr, L., Eyde, L. D., Hesketh, B., ... Sanchez, J. I. (2000). The practice of competency modeling. Personnel Psychology, 53(3), 703-740.

Smith, W. K., \& Tushman, M. L. (2005). Managing strategic contradictions: A top management model for managing innovation streams. Organization Science, 16(5), $522-536$.

Starbuck, W. H., \& Milliken, F. J. (1988). Challenger: Fine-tuning the odds until something breaks. Journal of Management Studies, 25(4), 319-340.

Thompson, J. D. (1967). Organizations in action: Social science bases of administrative theory. Transaction publishers.

Tushman, M. L., \& Romanelli, E. (1985). Organizational evolution: Interactions between external and emergent processes and strategic choice. Research in Organizational Behavior, 8, 171-222.

Uhl-Bien, M., Marion, R., \& McKelvey, B. (2007). Complexity leadership theory: Shifting leadership from the industrial age to the knowledge era. The Leadership Quarterly, 18(4), 298-318.

Yi, S., Knudsen, T., \& Becker, M. C. (2016). Inertia in routines: A hidden source of organizational variation. Organization Science, 27(3), 782-800.

Yusuf, Y. Y., Sarhadi, M., \& Gunasekaran, A. (1999). Agile manufacturing: The drivers, concepts and attributes. International Journal of Production Economics, 62(1), 33-43.

Zollo, M. (2009). Superstitious learning with rare strategic decisions: Theory and evidence from corporate acquisitions. Organization Science, 20(5), 894-908.

Zollo, M., \& Winter, S. G. (2002). Deliberate learning and the evolution of dynamic capabilities. Organization Science, 13(3), 339-351.

\section{Further Reading}

Cockburn, A., \& Williams, L. (2001). Extreme Programming Examined. AddisonWesley223-243.

Forsythe, C. (1997). Human factors in agile manufacturing: a brief overview with emphasis on communications and information infrastructure. Human Factors and Ergonomics in Manufacturing \& Service Industries, 7(1), 3-10.

Gehani, R. R. (1995). Time-based management of technology: a taxonomic integration of tactical and strategic roles. International Journal of Operations \& Production Management, 15(2), 19-35.

Gersick, C. J. (1988). Time and transition in work teams: Toward a new model of group development. Academy of Management Journal, 31(1), 9-41.

Goldman, S. L., Nagel, R. N., \& Preiss, K. (1995). Agile Competition and Virtual Organisations. New York, NY: Van Nostran Reinhold.

Lee, G., \& Xia, W. (2010). Toward agile: an integrated analysis of quantitative and qualitative field data on software development agility. Mis Quarterly, 34(1), 87-114.

Lyytinen, K., \& Rose, G. M. (2006). Information system development agility as organizational learning. European Journal of Information Systems, 15(2), 183-199. 